recognised teachers and others engaged in the internal work of the University. Its present president is Sir Joseph Walton, its past presidents have been the Right Honourable Lord Justice Fletcher Moulton and the present vice-chancellor of the University. All these distinguished men would have refused to be connected with the association had it desired to represent the views of external students alone. Indeed, it is this essential and consistent absence of all narrow partisanship which has helped to give our association such a predominant following among the graduates.

My Council feels assured that it is only necessary to draw your attention to these facts in order to convince you that the association is as anxious as the union can possibly be to promote the welfare of the University as a whole.

I am, Sirs, jours faithfully,

$$
\text { WALTER R. WARREN, }
$$

Hon. Gen. Secry., Univ. of London Graduates' Assocn. 2, Hare-court, Temple, Dec. 10th, 1907.

\section{"THE DANGERS OF CELLULOID."}

\section{To the Editors of THE LANCET.}

SIRS, - Our attention has been called to an erroneous and misleading article headed "The Dangers of Celluloid," which appears in THE LANCET of Dec. 7th, and we shall be glad if you will inform us where you obtained this information and why you published it without taking any steps to verify it. As the publication of such an article in a paper of such far-reaching influence as yours is calculated to damage us very considerably in our work we call upon you for an immediate apology and full contradiction in accordance with the facts of the case.

Taking the mis-statements in the order of their occurrence in the article in question, you first state "the ignition of this film was sufficient to involve very rapidly the entire factory in flames." The building is not a factory in the ordinary sense of the term, but a photographic studio and dark-rooms in which photographic images are produced upon sensitised cinematograph film by the usual photographic processes. Please note that the film comes to us from America already manufactured and sensitised. The entire building was not involved in the flames, only one small portion (about one-quarter) being affected.

You next state that there were 27 miles of celluloid film on the premises and that "it is quite evident that if fire had reached them an enormous conflagration, if not explosion, would have ensued." As a matter of fact, the entire film contents of the premises measured 158,000 feet, or, roughly, $29 \frac{3}{4}$ miles. Of this, 144,000 feet, or $27_{\frac{1}{4}}$ miles, was consumed in the fire, and there was neither any sign of explosion nor even noticeably large conflagrations. The entire remainder of the film which was saved and which you appear to regard as a menace to the neighbourhood measured 14,000 feet, or in round numbers $2 \frac{1}{4}$ miles. In other words, ten-elevenths of the entire stock was burnt, one-eleventh was saved. Apparently you have a very erroneons conception of what a mile of cinematograph film represents in the matter of bulk. For your information we may state that the film is stored in cylindrical tin boxes measuring $6 \frac{1}{4}$ inches across and $8 \frac{1}{4}$ inches deep. Each of these boxes contains 2000 feet, or well over one-third of a mile. 100 feet of film weighs just under 7 ounces, and that is not all celluloid.

The occurrence of this fire has proved conclusively that the existence of such "a factory" as ours is not a risk to surrounding property, and the fact that the outbreak was stopped with far more ease than it has ever been possible to stop a fire in a private house in Walton has clearly proved that there is no more danger to surrounding property than if the building were a private house. We may mention in this connexion that the captain of the fire brigade (who is also the council surveyor and perfectly familiar with the premises) did not state at the inquest that he considered the place to be a private building. He said he regarded it as a photographic studio.

We must ask you to give at least equal prominence to this letter or to a sufficient other contradiction of your mis-statements as that which you gave to the original article. Yours faithfully,

For the HEPWORTH M'F'G. Co., LTD., C. PARfrey, Secretary.

15, 17, Cecil-court, Charing Cross-road, London, W.C., Dec. 9th, 1907.

Theatre and Factories : Walton-on-Thames.

\section{ON MOBILITY OF THE KIDNEYS.}

\section{To the Editors of THE LANCET.}

SIRS,-The discussion of the question of mobility of the kidneys recalls to me the following case which impressed me much at the time and may be worth recording; it represents, at any rate, the proverbial ounce of fact, and so far as it goes it supports the contention of Dr. Hector Mackenzie that a mobile kidney, even when present in a case of hypo. chondriasis, is not necessarily the cause of the nervous symptoms.

In October, 1899, I was called to see Mrs. Z in the following circumstances. The wife of a well-to-do farmer and the mother of a grown-up family, Mrs. Z had been for several years suffering from dyspeptic hypochondriasis of increasing severity. She had been a patient of Dr. X, but a week before I saw her she had consulted Dr. Suckling. Dr. Suckling found a mobile right kidney and expressed his opinion that this was the cause of her symptoms, advising treatment by a belt. One result of this discovery was that the patient insisted on changing her doctor, saying that she could have no further confidence in one who had for so long overlooked the cause of her illness. It was in vain that I combated this decision. She presented when I first saw her a typical picture of hypochondriasis; her depression was intense and she had long been incapable of the slightest exertion although previously an active, hard-working woman. She was much emaciated, with sunken features and a yellowishwhite complexion, and the abdomen was flaccid and pendulous, so that it was particularly easy to palpate the internal organs. Belts and bandages were tried with no appreciable benefit and after about six months of treatment, during which time no real improvement took place, she gradually ceased doctoring. Some 18 months afterwards I was astonished to see Mrs. $Z$ walk into my surgery looking a picture of health. When I inquired what had cured her she told me with a good deal of diffidence that she had been persuaded to take a course of - pills, although she had no faith in patent nostrums, and that her condition had improved so rapidly that within four or five weeks she was practically a different woman. She had gained her original weight, had a good appetite and colour, slept well, and was fit for a good day's work. As far as I know her cure has been permanent and she remains well to this day. She had taken courses of iron of various kinds when under medical treatment. It seems to me that a variety of fairly obvious morals may be drawn from this case. Bromsgrove, Dec. 3rd, 1907. I am, Sirs, yours faithfully, CAMERON KIDD,

\section{FORMIC ACID AND THE FORMATES.}

\section{To the Editors of THE LANCET.}

SIRS,-As regards Mr. J. S. Mackintosh's letter in your issue of Dec. 7th $r e$ the action of formic acid and a diet of ants, perhaps he and other of your readers may find the following extract from "The New London Dispensatory" of 1676 of interest. In Book II., "Of Insects" p. 260, there is a

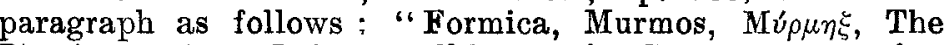
Pismire, or Ant. It is a small but a wise Creature, gathering its food in Summer in the full Moons, and resting in the new Moons: They are like a Common-wealth, and gather Corn, which they dry, and bite at both ends, that they may not grow: They wear away Stones by their assiduity, and make beaten Roadways; they help one another in drawing their burthens, dam out water, and bury their dead. The greater lead the way, and the lesser drag the Corn ; and when dirty, they cleanse themselves before they enter into their habitations : They teach the young to labour, but expel the idle, and when they carry their grain, it's said to be a sign of foul weather. 'They cast $n p$ the Earth over the mouths of their Caves (that the water may not enter in) wherein they have three Cells ; in the one they live, in another they breed and bury, and in the third they keep their Corn. They generate in Winter, bring forth Eggs, which in Spring are Ants; when old, they grow winged, and then suddenly after die. 1 . The Ants are hot and dry, excite Lust, and by their sharp scent, wonderfully refresh the Spirit: the greater and winged, with a little salt, cure the Psora, or Scab, and Leprosie. 2. Their Higgs help thickness of hearing and deafness : being rub'd on the skin, make it smooth, and taken inwardly expel wind. 3. Their Eggs with Bats blood is a depilatory, used three or four times a day. 4. The Acervus, or Ant-hill, strengthens the nerves, is Anodyne, and helps Gouts, Palsies, Convulsions, and Suffocation of the Womb being applied. 5. The Oyl of 